\title{
An Empirical Study on the Impact of HRD Practices on NPOs in Utilizing Foreign Contributions Received
}

\author{
${ }^{1}$ Apoorva B. Satish, ${ }^{2}$ Dr. Rechanna \\ ${ }^{1}$ Research Scholar, JSS Research Foundation, SJCE Mysuru. \\ ${ }^{2}$ Research Guide, JSS Research Foundation, SJCE Mysuru. \\ lapoorvaresearch91@gmail.com \\ ${ }^{1}$ 0000-0003-0538-1589
}

\begin{tabular}{|c|c|}
\hline Article History & Abstract \\
\hline $\begin{array}{l}\text { Article Submission } \\
20 \text { December } 2021 \\
\text { Revised Submission } \\
15 \text { January } 2022 \\
\text { Article Accepted } \\
02 \text { February } 2022 \\
\text { Article Published } \\
09 \text { February } 2022\end{array}$ & $\begin{array}{l}\text { Nonprofit organizations in India represent a significant portion and they make a } \\
\text { strong contribution to the economic wellbeing of our country. The human resources } \\
\text { are vital for achieving the sustainable growth and development of organization. } \\
\text { Firstly, objective is to analyze the workforce perception of NPOs towards the HRD } \\
\text { practices of NPO. Secondly, the amount of FCR and FCU by NPOs are analyzed } \\
\text { and compared. Thirdly, the efficiency of NPOs is measured based on their HRD } \\
\text { practices. Lastly the impact of HRD practices on the efficiency of NPOs are } \\
\text { measured. Based on the objective's hypothesis were formulated and tested. The study } \\
\text { found that the NPO's workforce has positively perceived HRD practices followed in } \\
\text { their organization. The respondents have agreed and given a positive opinion } \\
\text { towards the HRD practices viz., appraisal system, Training and development, career } \\
\text { development and recognition, and organizational environment followed in their } \\
\text { organizations. The study found that HRD practices have a significant positive impact } \\
\text { on the development of NPOs in Karnataka. Large-sized NPOs are generating larger } \\
\text { amount, whereas small-sized NPOs are acquiring lesser number of foreign } \\
\text { contributions. NPOs with better HRD practices are efficient in utilizing the foreign } \\
\text { contributions received by them. The efficiency of the NPOs increases as they adapt } \\
\text { better HRD practices, and the efficiency of NPOs decrease as they ignore HRD } \\
\text { practices. } \\
\text { Keywords: Human Resource Development Practices; Non- Profit Organizations; } \\
\text { Foreign contributions received; Foreign contributions utilized; Efficiency analysis }\end{array}$ \\
\hline
\end{tabular}

\section{Introduction}

Nonprofit organizations play a vital role in the socio-economic development of a country. The importance of voluntary organizations is increasing over time. In a democratic system, the state's role is prime and most significant in formulating and implementing developmental projects and policies. However, in present society, people's problems, especially the poor, are much more complex. Such disparities are especially true in India, where numerous vulnerable sections are experiencing inequalities at all levels. Growth does not only indicate socio-economic development but also involves promoting equality. It is not possible for the Government alone to efficiently tackle such complex development ventures. So, there is a requirement for other groups or organizations to support the Government in various aspects. This essentiality tiled the way for the emergence of civil society. Nonprofit Organizations are a significant arm of civil society and thus have a crucial role in the country's development process. NPOs play an active role globally in strengthening communities, assisting governments, and promoting the wellbeing of citizens, along with many crucial dimensions (Weisbrod, 1988). For the development of NPOs human resources of the organizations play a significant role. The human resource of NPOs is the main stakeholders to be considered while formulating plans. The employees and volunteers of NPOs are affected by intrinsic values and motivated by these values. Human resources being the necessary 
component of an organization's success, this study focuses on linking the HRD practices of NPOs with the development of NPOs and improving the efficiency of NPOs.

\section{Theoretical Aspect}

Human Resource Development (HRD): Human Resource Development (HRD) is the structure for helping employees in an organization to advance their personal and professional skills and expertise. HRD includes elements such as training and development, performance management, and career development. The focus of aspects of HRD is strengthening the workforce so that the organization and individuals can fulfill their aims. Organizations may possess resources for developing the human resources in their organization, but the challenging task is to identify such opportunities and utilize them appropriately and efficiently.

Non-profit organization: A Nonprofit Organization (NPO) is an organization established to achieve mission goals rather than profit. The NPO utilizes surplus revenues generated for accomplishing mission instead of distributing them as profits or dividends to shareholders.

\section{Literature Review}

A study by Chang et al (2015) focuses on the employee training in NPOs. They studied smaller NPOs in Taiwan (China). They found that widely used linear training design, implementation, and methods are not appropriate for many non-profits due to organizational factors. Workforce learning has gained massive importance in non-profits. Due to the influence of organizational factors, training method has changed in NPOs, and diverse on-the-job approaches are adopted.

The study by Gyambrah (2017) examined the HRD practices of NGOs in Ghana, with a particular focus on NGOs in the health sector. The study combines mixed research methods. The author used a sample size of 30 NGOs registered with the Department of social welfare. Descriptive statistics was used to analyse the data. The study observed that although NGOs in Ghana's health sector employ some HRD practices, much attention is not given to these practices. Therefore, the study recommended that Human resource development be appropriately introduced to the NGOs as it helps maintain talents in workers due to the capacity training attended.

Kim and Park (2016) conducted a study on the performance appraisal system in Korean NPOs. The study links between performance appraisal and workers' motivation in NPOs. The study found that acceptance of a performance appraisal system (APAS) positively relates to workers' cause. Organizational characteristics that affect Korean non-profit employees are discussed in detail.

A study on Attitude difference between the paid employees and volunteers was conducted by Liao-Troth (2001). The study found that the psychological contract was substantially similar between paid employees and volunteers, except psychological contracts regarding benefits. In addition, organizational commitment and organizational justice was substantially similar between paid employees and volunteers, except the continuance dimension of organizational commitment. The study found similarity of job attitudes among volunteers and paid workers.

Taylor and Graw (2006) conducted a study on HRM practices in Non-profit Sports Organisations. The research focuses on adopting HRM practices by state sports organizations in New South Wales, Australia. Study results indicate that despite pressures to become more strategic in their people management, only a minority of sports organisations have formal HRM systems. The study states practical implications for HRM in sport organizations and discusses future challenges.

\section{Research Gap}

In all the studies reviewed here it can be seen that NPOs play a prominent role in building nation. There are several studies on NPOs across different countries. In Indian scenario there are studies related to NPOs but very few can be related to the HRD in NPOs. Likewise, there are numerous studies on HRD in different sectors but very few on HRD in NPOs only. Hence the present study was undertaken to study the efficiency of NPOs based on HRD practices in Karnataka. 


\section{Objectives of the Study}

In background of the research questions the following objectives are were framed.

1. To analyze the perception of the NPO's workforce towards HRD practices followed in their organization.

2. To compare the number of foreign contributions received and utilized by NPOs.

3. To compare the efficiency of large, medium, and small-sized NPOs based on their HRD practices.

4. To measure the impact of HRD practices on the efficiency of NPOs in utilizing foreign contributions.

\section{Methodology}

The present study follows a research methodology to explore the HRD practices of NPOs in Karnataka. All Nonprofit organizations registered under the Foreign Contribution (Regulation) Act, 2010 (FCRA) of Karnataka State constitute the population. For the study purpose, only a sample of the population has been studied. Ninety NPOs registered on the FCRA website are chosen for the study. Five respondents from each NPO were selected, and the researcher collected respondents' perceptions of HRD practices. The responses from 450 respondents are classified into different groups and subgroups. Cronbach's Alpha test was conducted to measure the reliability of variables considered for the study. The test results indicated that all the variables had crossed the threshold value $(>0.7)$ and were acceptable. The HRD practices adopted by NPOs are discussed in addition to perception analysis of employees and volunteers. Further, the impact of HRD practices on the development of NPOs is measured using regression. NPOs receive funds from several sources. Since the present sample is on the NPOs which receive foreign contributions, detailed analysis regarding the contributions is made. First, the FC Received and utilized by NPOs are analyzed in detail. Later, they are classified into large-sized NPOs, mediumsized NPOs, and small-sized NPOs based on foreign contributions received. In addition to the size classification, they are categorized into three levels based on their utilization level of contributions received. The efficiency of NPOs is measured based on the HRD practices followed by them. To measure the efficiency of NPOs ANOVA test was applied. Further, the impact of HRD practices on NPOs in utilizing contributions is analyzed. Regression analysis was conducted to test the hypothesis.

\section{A.Sample design}

A sample design is a definite plan or procedure adopted for obtaining sample from population. It is aimed at achieving a certain confidence level that the true characteristics of a population are well accommodated in the sample. Sampling design serves many purposes like saving time and money, more accurate measurement, and high feasibility when population contains infinitely many numbers. The sampling design mainly consists of population, distribution of sample units and sample profile.

\section{B. Population distribution}

There are several NPOs operating in the state, but the present study is confined to registered NPOs in Karnataka State. All Non-Profit organizations registered under FCRA of Karnataka State constitute the population. The base year for considering the population and sample is ' $2014-15$ '. From the FCRA website it is found that 1824 NPOs have registered in the base year. For the study purpose only a sample of population is studied.

\section{C.Sample distribution}

For the present study a sample of 90 NPOs are drawn from the population of NPOs registered under FCRA of Karnataka State. Judgment sampling method was used to select 90NPOs from the population. Based on the availability of data regarding the annual returns of NPOs of five years the sample NPOs were chosen. They were stratified by size and utilization capacity.

The sample consists of 90NPOs. 30 NPOs were large in size, 30 NPOs were medium in size and 30 NPOs were small in size. The base for stratification of NPOs into large, medium and small size was foreign contribution received by NPOs. Large NPOs were with contributions above Rs. 3.18 crore medium size NPOs were with contributions in between Rs. 40 lakhs to Rs. 3.18 crore and small size NPOs were with contributions below Rs. 40 lakhs. 


\section{Reliability}

The most popular test of inter item consistency reliability is the Cronbach's alpha (Cronbach, 1984), the value of alpha ranges from $0-1$. The nearer the value of alpha to 1 , the better the reliability is. If the value is low, either there are too few items or there is very little commonality among the items. Typically, reliability coefficient of 0.7 or more are considered adequate (Cronbach, 1984; Nunnally, 1978). Table 1 presents the reliability test results of the present study.

Table 1: Reliability test results

\begin{tabular}{|l|c|c|c|c|}
\hline \multicolumn{1}{|c|}{ Variables } & $\begin{array}{c}\text { No. of } \\
\text { items }\end{array}$ & Mean & $\begin{array}{c}\text { Standard } \\
\text { deviation }\end{array}$ & $\begin{array}{c}\text { Cronbach's } \\
\text { Alpha Score }\end{array}$ \\
\hline Appraisal system & 5 & 3.47 & .91 & 0.94 \\
\hline Training and development & 5 & 3.47 & .86 & 0.93 \\
\hline Career development and recognition & 5 & 3.46 & .89 & 0.95 \\
\hline Organizational environment & 5 & 3.48 & .86 & 0.95 \\
\hline Overall HRD Practices & 20 & 3.46 & .80 & 0.96 \\
\hline Development of NPOs & 6 & 3.50 & .90 & 0.91 \\
\hline
\end{tabular}

Source: SPSS Output

The Cronbach's Alpha Score values of the stated variables are greater than the prescribed threshold of 0.7 (Cronbach, 1951; Nunnally, 1978) hence the scale is sound and reliable. SPSS statistical software was used to measure the reliability.

\section{Analysis And Findings}

The current HRD practices followed in NPOs have been studied and analyzed under four divisions viz., HRD Practice Appraisal system; HRD Practice Career development and recognition; HRD Practice Training; HRD Practice Organizational environment and overall HRD practices.

H0: The NPO's workforce has negatively perceived HRD practices followed in their organization.

H1: The NPO's workforce has positively perceived HRD practices followed in their organization.

Table 2: Hypothesis test results of Overall HRD Practice

\begin{tabular}{|c|c|c|c|c|}
\hline \multirow{2}{*}{ Dimension } & $\begin{array}{c}\text { Mean } \\
\text { value }\end{array}$ & $\begin{array}{c}\text { Standard } \\
\text { deviation } \\
\text { value }\end{array}$ & t- value & p- value \\
\hline HRD 1: Appraisal system & 3.4711 & .90930 & 10.991 & .000 \\
\hline HRD 2: Training and development & 3.4769 & .86302 & 11.722 & .000 \\
\hline HRD 3: Career development and recognition & 3.4600 & .88585 & 11.016 & .000 \\
\hline HRD 4: Organizational environment & 3.4782 & .85975 & 11.800 & .000 \\
\hline Overall HRD Practices & 3.4561 & .79935 & 12.103 & .000 \\
\hline
\end{tabular}

*Significance at 0.05 Source: Field survey (SPSS Output)

From the table 2 it is evident that the NPO's workforce has positively perceived HRD practices followed in their organization. Based on the mean values and Standard deviation values there is a positive perception of employees and volunteers towards the HRD practices in NPOs. The $\mathrm{p}$ values for all the HRD practices are .000 . Therefore, the null hypothesis is rejected and alternative hypothesis is accepted. 


\section{Comparison of the Foreign Contributions received and utilized}

Based on the contributions received and utilized a comparison is made between the two. It is important for NPOs to generate funds at the same time they are responsible for the appropriate utilization of contributions received. Table 3 compares the FC Received with FC utilized.

Table 3: Comparison of the Foreign Contributions received and utilized

\begin{tabular}{|c|c|c|c|c|c|}
\hline Particulars & $\mathbf{2 0 1 4 - 1 5}$ & $\mathbf{2 0 1 5 - 1 6}$ & $\mathbf{2 0 1 6 - 1 7}$ & $\mathbf{2 0 1 7 - 1 8}$ & $\mathbf{2 0 1 8 - 1 9}$ \\
\hline Balance b /f & 17.06 & 212.03 & 243.80 & 269.01 & 315.33 \\
\hline $\begin{array}{c}\text { Interests and other } \\
\text { receipts }\end{array}$ & 139.65 & 125.83 & 7.01 & 41.06 & 62.03 \\
\hline $\begin{array}{c}\text { FC received during } \\
\text { the current year }\end{array}$ & 493.84 & 590.34 & 698.69 & 681.52 & 652.49 \\
\hline Total FC received & 650.55 & 928.20 & 949.50 & 991.58 & 1029.85 \\
\hline FC Utilized & 438.52 & 684.40 & 680.49 & 676.25 & 784.09 \\
\hline $\begin{array}{c}\text { Unutilized amount } \\
\text { c/f }\end{array}$ & 212.03 & 243.80 & 269.01 & 315.33 & 245.76 \\
\hline
\end{tabular}

Table 3 presents the comparison of FC Received and FC utilized. Both are depicting an increasing trend. The contributions received are not completely utilized. This trends analysis shows overall pattern of the funds received and utilized by NPOs. For better understanding the entire sample is divided into large size, medium size and small size NPOs based on Foreign Contributions received. To know the level of utilization of contributions, sample set is divided into three levels of utilization viz.; High level, medium level and low level of utilization.

\section{A.Efficiency of NPOs Based on HRD Practices}

To measure the efficiency of NPOs in utilizing the foreign contributions the HRD practices act as a base for analysis. The perception of respondents towards the various HRD practices followed in their organization is measured using a five-point Likert scale. Their agreement towards a statement is noted as five points and disagreement is noted as one point. The responses were classified into size categories and utilization categories for presentation purpose.

\section{B. Comparison of efficiency of large, medium and small size NPOs based on their HRD practices.}

First the overall comparison of large medium and small size NPOs is made. Further the comparison of large medium and small sizes is analyzed individually. The average score of all respondents (450 respondents) regarding HRD practices is combined to obtain the mean value of NPOs.

To compare the efficiency of large, medium and small size NPOs based on their HRD practices following hypothesis was formulated.

$\mathrm{H}_{0}$ : There is no significant difference in the efficiency of large, medium and small size NPOs based on their HRD practices.

$\mathrm{H}_{1}$ : There is significant difference in the efficiency of large, medium and small size NPOs based on their HRD practices.

Based on the mean value is evident that large size NPOs are having higher mean value compared to small size NPOs. ANOVA table shows that there is no significant difference in the efficiency of large, medium and small size NPOs based on their HRD practices. The p-value $<.05$ hence the research hypothesis is accepted. Here the overall comparison is made between the NPOs of different sizes. But to analyze the efficiency of NPOs in utilizing the foreign contributions the sizes are further classified into levels of utilization and are analyzed separately. 
Table 4: Comparison of HRD practices of large medium and small size NPOs.

\begin{tabular}{|c|c|c|c|}
\hline Size of NPOs & $\mathbf{N}$ & Mean value & Standard deviation \\
\hline Large size & 150 & 3.82 & .74 \\
\hline Medium size & 150 & 3.47 & .70 \\
\hline Small size & 150 & 3.07 & .78 \\
\hline Total & 450 & 346 & .80 \\
\hline
\end{tabular}

Table 5: ANOVA table for comparison of HRD practices of large medium and small size NPOs.

\begin{tabular}{|c|c|c|c|c|c|}
\hline & Sum of squares & df & Mean square & F -value & Significance \\
\hline Between groups & 42.28 & 2 & 21.14 & & \\
\cline { 1 - 3 } Within groups & 244.62 & 447 & .55 & \multirow{2}{*}{38.63} & .000 \\
\cline { 1 - 3 } Total & 286.90 & 449 & & & \\
\hline
\end{tabular}

Table 6: Comparison of HRD Practices in Large, medium and small Size NPOs

\begin{tabular}{|l|l|l|l|l|l|l|}
\hline HRD Practices -Dimensions/Variables & \multicolumn{2}{l|}{ Large } & \multicolumn{2}{l|}{ Medium } & \multicolumn{2}{l|}{ Small } \\
\cline { 2 - 9 } & Mean & $\begin{array}{l}\text { Std } \\
\text { dev }\end{array}$ & Mean & $\begin{array}{l}\text { Std } \\
\text { dev }\end{array}$ & Mean & $\begin{array}{l}\text { Std } \\
\text { dev }\end{array}$ \\
\hline Appraisal system & $\mathbf{3 . 8 6}$ & $\mathbf{0 . 8 0}$ & $\mathbf{3 . 5 1}$ & $\mathbf{0 . 7 7}$ & $\mathbf{3 . 0 4}$ & $\mathbf{0 . 9 5}$ \\
\hline $\begin{array}{l}\text { Promotion decisions are based on the suitability of the } \\
\text { promotee }\end{array}$ & 3.97 & 0.74 & 3.61 & 0.78 & 3.15 & 0.87 \\
\hline $\begin{array}{l}\text { Performance appraisal reports are based on objective } \\
\text { assessment and adequate information and not on any } \\
\text { favoritism. }\end{array}$ & 3.94 & 1.02 & 3.57 & 0.94 & 2.88 & 1.24 \\
\hline $\begin{array}{l}\text { The appraisal data are used by the HRD department for } \\
\text { taking development decisions. }\end{array}$ & 3.58 & 0.90 & 3.31 & 0.91 & 3.05 & 0.85 \\
\hline $\begin{array}{l}\text { Managers and supervisors regularly supervise their } \\
\text { subordinates }\end{array}$ & 4.06 & 0.98 & 3.59 & 0.96 & 2.96 & 1.32 \\
\hline Performance appraisals are done at regular intervals & 3.75 & 0.98 & 3.46 & 0.81 & 3.18 & 0.89 \\
\hline Training and development & $\mathbf{3 . 7 7}$ & $\mathbf{0 . 9 3}$ & $\mathbf{3 . 4 7}$ & $\mathbf{0 . 8 6}$ & $\mathbf{3 . 1 2}$ & $\mathbf{0 . 9 8}$ \\
\hline $\begin{array}{l}\text { Top management encourages employees/volunteers for } \\
\text { training }\end{array}$ & 3.82 & 0.90 & 3.51 & 0.84 & 3.32 & 0.87 \\
\hline $\begin{array}{l}\text { Employees/volunteers are sponsored for training programs } \\
\text { based on genuine training needs. }\end{array}$ & 3.80 & 1.16 & 3.47 & 1.11 & 3.03 & 1.35 \\
\hline $\begin{array}{l}\text { NPO organizes training programs for employees/ } \\
\text { volunteers }\end{array}$ & 3.57 & 0.96 & 3.41 & 0.80 & 3.11 & 0.84 \\
\hline Training programs are organized regularly & 3.83 & 1.15 & 3.43 & 1.10 & 3.09 & 1.38 \\
\hline $\begin{array}{l}\text { Trainees are given opportunities to try new methods learnt } \\
\text { in the training program }\end{array}$ & 3.83 & 0.98 & 3.54 & 0.86 & 3.25 & 0.91 \\
\hline Career development and recognition & $\mathbf{3 . 8 6}$ & $\mathbf{0 . 7 9}$ & $\mathbf{3 . 5 2}$ & $\mathbf{0 . 8 0}$ & $\mathbf{3 . 0 6}$ & $\mathbf{0 . 9 8}$ \\
\hline $\begin{array}{l}\text { Career opportunities are pointed out to subordinates by } \\
\text { seniors }\end{array}$ & 3.83 & 0.89 & 3.57 & 0.78 & 3.17 & 0.91 \\
\hline $\begin{array}{l}\text { Seniors guide their juniors and prepare them for future } \\
\text { responsibilities }\end{array}$ & 4.05 & 0.96 & 3.59 & 1.05 & 3.01 & 1.35 \\
\hline Job performed is valued appropriately & 3.55 & 0.92 & 3.40 & 0.79 & 3.01 & 0.82 \\
\hline $\begin{array}{l}\text { There are mechanisms in this NPO to reward any good } \\
\text { work done or any contribution made by employees/ } \\
\text { volunteers }\end{array}$ & 4.05 & 0.94 & 3.51 & 1.05 & 2.97 & 1.30 \\
\hline
\end{tabular}




\begin{tabular}{|l|l|l|l|l|l|l|}
\hline $\begin{array}{l}\text { Top management recognizes and appreciates the good } \\
\text { work of employees/volunteers }\end{array}$ & 3.84 & 0.94 & 3.51 & 0.84 & 3.17 & 1.00 \\
\hline Organizational environment & $\mathbf{3 . 7 8}$ & $\mathbf{0 . 9 4}$ & $\mathbf{3 . 4 2}$ & $\mathbf{0 . 8 8}$ & $\mathbf{3 . 0 1}$ & $\mathbf{0 . 9 5}$ \\
\hline $\begin{array}{l}\text { When seniors delegate authority, the juniors use it as an } \\
\text { opportunity for } \\
\text { development }\end{array}$ & 3.82 & 0.91 & 3.47 & 0.86 & 3.19 & 0.86 \\
\hline $\begin{array}{l}\text { When behavior feedback is given to employees/ volunteers } \\
\text { they take it seriously and use it for development. }\end{array}$ & 3.85 & 1.15 & 3.39 & 1.11 & 2.77 & 1.24 \\
\hline People in this NPO are helpful to each other. & 3.55 & 0.96 & 3.34 & 0.84 & 3.07 & 0.80 \\
\hline There is a high degree of team spirit in this organization. & 3.93 & 1.13 & 3.45 & 1.11 & 2.89 & 1.35 \\
\hline $\begin{array}{l}\text { Organization plans and policies are clear and well } \\
\text { communicated to employees / volunteers }\end{array}$ & 3.76 & 1.02 & 3.45 & 0.89 & 3.13 & 0.86 \\
\hline
\end{tabular}

\section{Comparison Of HRD Practices in Large Size NPOs}

The HRD practices of large size NPOs are presented in table 7. Here the NPOs are not classified into different utilization levels. All the 150 responses belonging to large size NPOs are considered. The HRD dimension 'Career development and recognition' has the highest mean (3.864) with standard deviation 0.79. Overall training has least mean of 3.77. This implies large size NPOs are providing adequate benefits to employees but they lack in training the employees.

Efficiency of large size NPOs

$\mathrm{H} 0$ : There is no significant difference in the HRD practices of large size NPOs belonging to different utilization levels.

H1: There is significant difference in the HRD practices of large size NPOs belonging to different utilization levels.

To test the formulated hypothesis ANOVA test was performed. The results are presented in table 7.

Table 7: ANOVA Table for Large Size NPOs

\begin{tabular}{|c|c|c|c|c|c|c|}
\hline HRD Practices/ Dimensions & Level of utilization & $\mathbf{N}$ & Mean & Std dev & $\mathrm{F}$ & Sig. \\
\hline \multirow{4}{*}{$\begin{array}{l}\text { HRD1 } \\
\text { Appraisal system }\end{array}$} & Low level & 35 & 3.6457 & .68785 & \multirow{4}{*}{8.287} & \multirow{4}{*}{.000} \\
\hline & Medium level & 65 & 3.7015 & .75674 & & \\
\hline & High level & 50 & 4.2200 & .82635 & & \\
\hline & Total & 150 & 3.8613 & .80233 & & \\
\hline \multirow{4}{*}{$\begin{array}{l}\text { HRD2 } \\
\text { Training }\end{array}$} & Low level & 35 & 3.5771 & .68043 & \multirow{4}{*}{9.416} & \multirow{4}{*}{.000} \\
\hline & Medium level & 65 & 3.5354 & .96443 & & \\
\hline & High level & 50 & 4.2120 & .89297 & & \\
\hline & Total & 150 & 3.7707 & .93044 & & \\
\hline \multirow{4}{*}{$\begin{array}{l}\text { HRD3 } \\
\text { Career development and recognition }\end{array}$} & Low level & 35 & 3.7029 & .49318 & \multirow{4}{*}{3.409} & \multirow{4}{*}{.036} \\
\hline & Medium level & 65 & 3.7723 & .78253 & & \\
\hline & High level & 50 & 4.0960 & .92515 & & \\
\hline & Total & 150 & 3.8640 & .79235 & & \\
\hline \multirow{4}{*}{$\begin{array}{l}\text { HRD4 } \\
\text { Organizational environment }\end{array}$} & Low level & 35 & 3.5257 & .68956 & \multirow{4}{*}{5.493} & \multirow{4}{*}{.005} \\
\hline & Medium level & 65 & 3.6585 & .85493 & & \\
\hline & High level & 50 & 4.1240 & 1.10057 & & \\
\hline & Total & 150 & 3.7827 & .93921 & & \\
\hline
\end{tabular}

Source: SPSS Output 


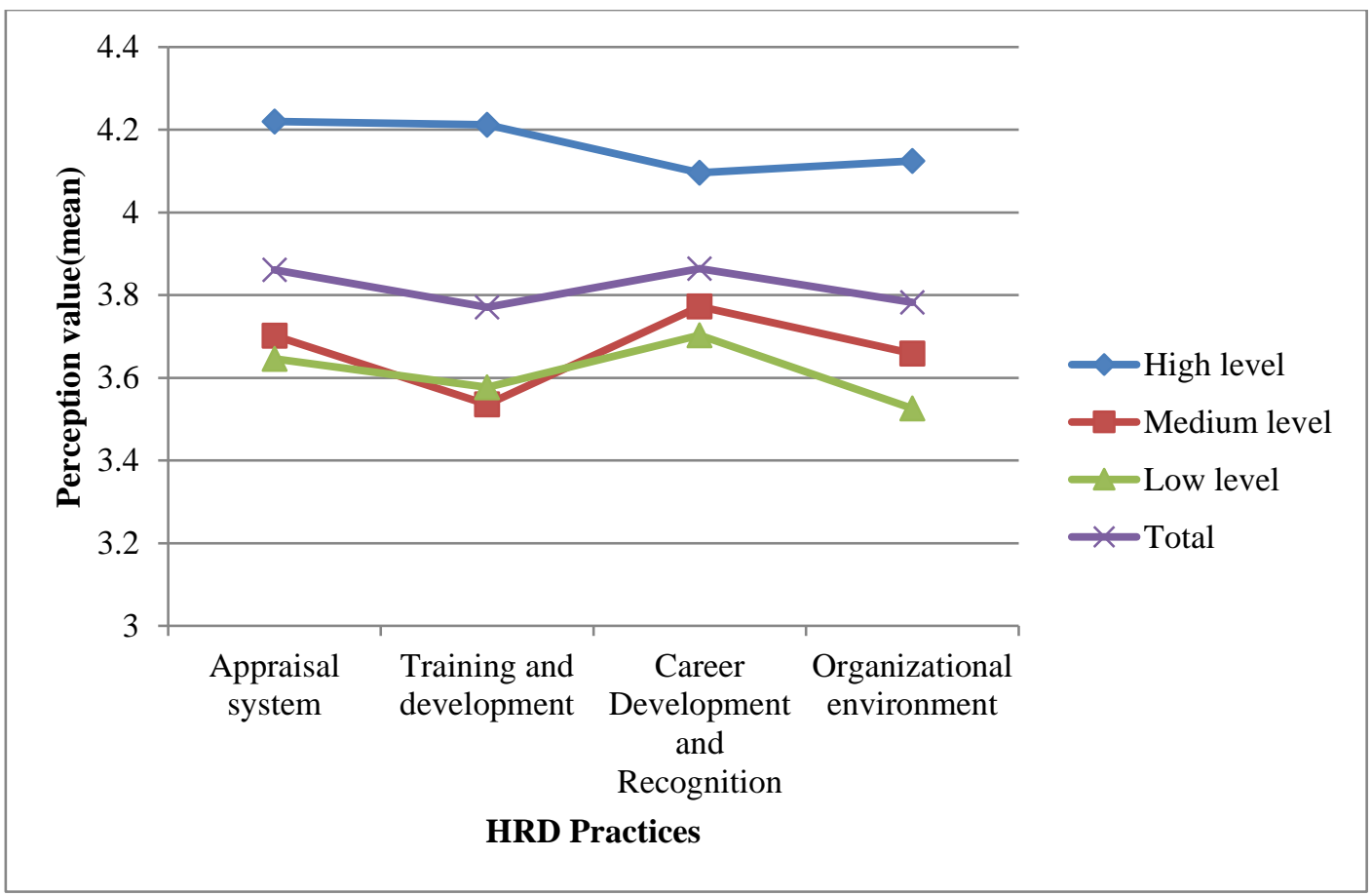

Source: Field survey (SPSS Output)

Figure 1: HRD practices of large size NPOs

From the ANOVA test results it is evident that HRD practices play a prominent role in utilizing the foreign contributions received by NPOs. The $\mathrm{p}$ value is $<0.05$ in all the cases. Therefore, the null hypothesis is rejected and the research hypothesis stands accepted. It can be observed from the table that when the HRD score is less the level of utilization is low and when the HRD score is high the utilization level is high. This implies for the better utilization of foreign contributions HRD practices are essential. Large size NPOs should adapt better HRD practices to utilize the contributions to the full extent. Overall, from the hypothesis testing it is clear that better HRD practices leads higher utilization of contributions and increases the efficiency of large size NPOs.

\section{Comparison Of HRD Practices in Medium Size NPOs}

The HRD practices of medium size NPOs are presented in table 8 . Here the NPOs are not classified into different utilization levels. All the 150 responses belonging to medium size NPOs are considered. The HRD dimension 'Career development and recognition' has the highest mean (3.51) with standard deviation 0.8. Overall Organizational environment has least mean of 3.42. This implies medium size NPOs are giving importance to 'career development and recognition' of employees and volunteers but they lack in maintaining favorable organizational environment.

Efficiency of medium size NPOs

$\mathrm{HO}$ : There is no significant difference in the HRD practices of medium size NPOs belonging to different utilization levels.

H1 : There is significant difference in the HRD practices of medium size NPOs belonging to different utilization levels.

To test the formulated hypothesis ANOVA test was performed. The results are presented in table 8

Table 8: ANOVA Table for Medium Size NPOs

\begin{tabular}{|l|c|c|c|c|c|c|}
\hline HRD Practices/ Dimensions & Level of utilization & $\mathbf{N}$ & Mean & Std dev & F & Sig. \\
\hline \multirow{2}{*}{$\begin{array}{l}\text { HRD1 } \\
\text { Appraisal system }\end{array}$} & Low level & 45 & 3.1556 & .48409 & \multirow{3}{*}{7.73} & \multirow{3}{*}{0.001} \\
\cline { 2 - 6 } & Medium level & 55 & 3.5927 & .56038 & \\
\cline { 2 - 6 } & High level & 50 & 3.7320 & 1.04480 & & \\
\hline
\end{tabular}




\begin{tabular}{|c|c|c|c|c|c|c|}
\hline & Total & 150 & 3.5080 & .77395 & & \\
\hline \multirow{4}{*}{$\begin{array}{l}\text { HRD2 } \\
\text { Training }\end{array}$} & Low level & 45 & 3.1422 & .57307 & \multirow{4}{*}{6.334} & \multirow{4}{*}{0.002} \\
\hline & Medium level & 55 & 3.4873 & .73913 & & \\
\hline & High level & 50 & 3.7480 & 1.08029 & & \\
\hline & Total & 150 & 3.4707 & .85864 & & \\
\hline \multirow{4}{*}{$\begin{array}{l}\text { HRD3 } \\
\text { Career development and recognition }\end{array}$} & Low level & 45 & 3.1822 & .53737 & \multirow{4}{*}{6.315} & \multirow{4}{*}{0.002} \\
\hline & Medium level & 55 & 3.5964 & .59441 & & \\
\hline & High level & 50 & 3.7280 & 1.07723 & & \\
\hline & Total & 150 & 3.5160 & .80377 & & \\
\hline \multirow{4}{*}{$\begin{array}{l}\text { HRD4 } \\
\text { Organizational environment }\end{array}$} & Low level & 45 & 3.1467 & .58837 & \multirow{4}{*}{4.366} & \multirow{4}{*}{0.014} \\
\hline & Medium level & 55 & 3.4145 & .83076 & & \\
\hline & High level & 50 & 3.6720 & 1.08403 & & \\
\hline & Total & 150 & 3.4200 & .88469 & & \\
\hline
\end{tabular}

Source: Field survey (SPSS Output)

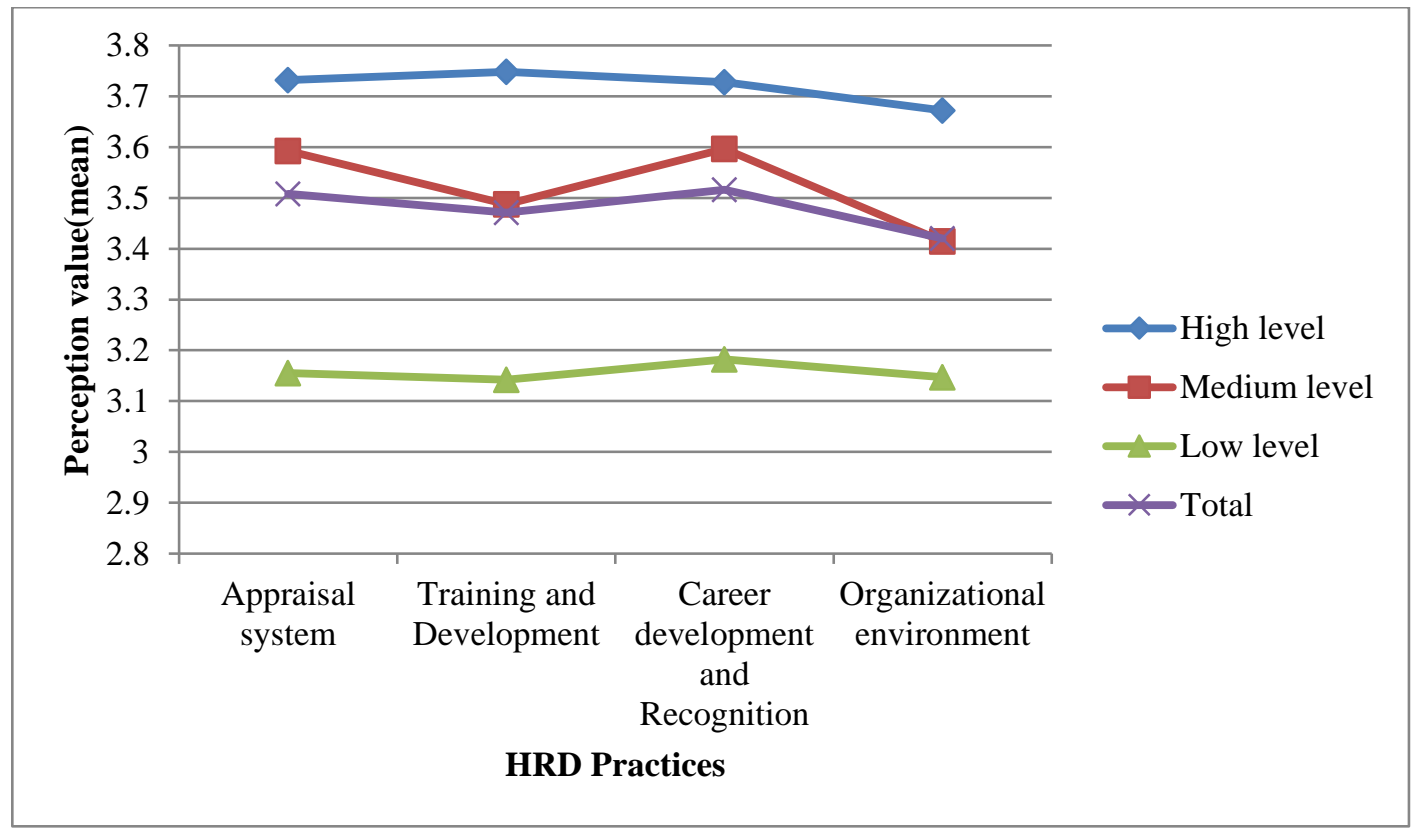

Source: Field survey (SPSS Output)

Figure 2: HRD practices of medium size NPOs

From the ANOVA test results it is evident that HRD practices play a prominent role in utilizing the foreign contributions received by NPOs. The $\mathrm{p}$ value is $<0.05$ in all the cases. Therefore, the null hypothesis is rejected and the research hypothesis "There is significant difference in the HRD practices of medium size NPOs belonging to different utilization levels" stands accepted. It can be observed from the table that when the HRD score is less the level of utilization is low and when the HRD score is high the utilization level is high. This implies for the better utilization of foreign contributions HRD practices are essential. Medium size NPOs should adapt better HRD practices to utilize the contributions to the full extent. Overall, from the hypothesis testing it is clear that better HRD practices leads higher utilization of contributions and increases the efficiency of medium size NPOs.

\section{E. Comparison of HRD Practices in Small Size NPOs}

The HRD practices of small size NPOs are presented in table 9. Here the NPOs are not classified into different utilization levels. All the 150 responses belonging to small size NPOs are considered. The HRD dimension 'Training' has the highest mean (3.16) with standard deviation 0.99. In particular HRD practice 
'Encouragement for training' has highest mean (3.32). Overall Organizational environment has least mean of 3.01. This implies small size NPOs have better training system but they lack in maintaining favorable organizational environment.

Efficiency of small size NPOs

$\mathrm{HO}$ : There is no significant difference in the HRD practices of small size NPOs belonging to different utilization levels.

H1: There is significant difference in the HRD practices of small size NPOs belonging to different utilization levels.

To test the formulated hypothesis ANOVA test was performed. The results are presented in table 9

Table 9: ANOVA Table for Small Size NPOs

\begin{tabular}{|c|c|c|c|c|c|c|}
\hline $\begin{array}{l}\text { HRD Practices/ } \\
\text { Dimensions }\end{array}$ & $\begin{array}{c}\text { Level of } \\
\text { utilization }\end{array}$ & $\mathbf{N}$ & Mean & Std dev & $\mathrm{F}$ & Sig. \\
\hline \multirow{4}{*}{$\begin{array}{l}\text { HRD1 } \\
\text { Appraisal system }\end{array}$} & Low level & 70 & 2.7743 & .78532 & \multirow{4}{*}{7.237} & \multirow{4}{*}{.001} \\
\hline & Medium level & 30 & 3.0467 & .62518 & & \\
\hline & High level & 50 & 3.4200 & 1.19198 & & \\
\hline & Total & 150 & 3.0440 & .95422 & & \\
\hline \multirow{4}{*}{$\begin{array}{l}\text { HRD2 } \\
\text { Training }\end{array}$} & Low level & 70 & 3.0057 & .82284 & \multirow{4}{*}{4.956} & \multirow{4}{*}{.008} \\
\hline & Medium level & 30 & 2.9467 & .61685 & & \\
\hline & High level & 50 & 3.5100 & 1.26204 & & \\
\hline & Total & 150 & 3.1620 & .98633 & & \\
\hline \multirow{4}{*}{$\begin{array}{l}\text { HRD3 } \\
\text { Career development } \\
\text { and recognition }\end{array}$} & Low level & 70 & 2.8000 & .85262 & \multirow{4}{*}{10.109} & \multirow{4}{*}{.000} \\
\hline & Medium level & 30 & 2.8800 & .48877 & & \\
\hline & High level & 50 & 3.5440 & 1.19115 & & \\
\hline & Total & 150 & 3.0640 & .98317 & & \\
\hline \multirow{4}{*}{$\begin{array}{l}\text { HRD4 } \\
\text { Organizational } \\
\text { environment }\end{array}$} & Low level & 70 & 2.7914 & .85698 & \multirow{4}{*}{6.415} & \multirow{4}{*}{.002} \\
\hline & Medium level & 30 & 2.8933 & .50578 & & \\
\hline & High level & 50 & 3.3880 & 1.16718 & & \\
\hline & Total & 150 & 3.0107 & .95448 & & \\
\hline
\end{tabular}

Source: Field survey (SPSS Output)

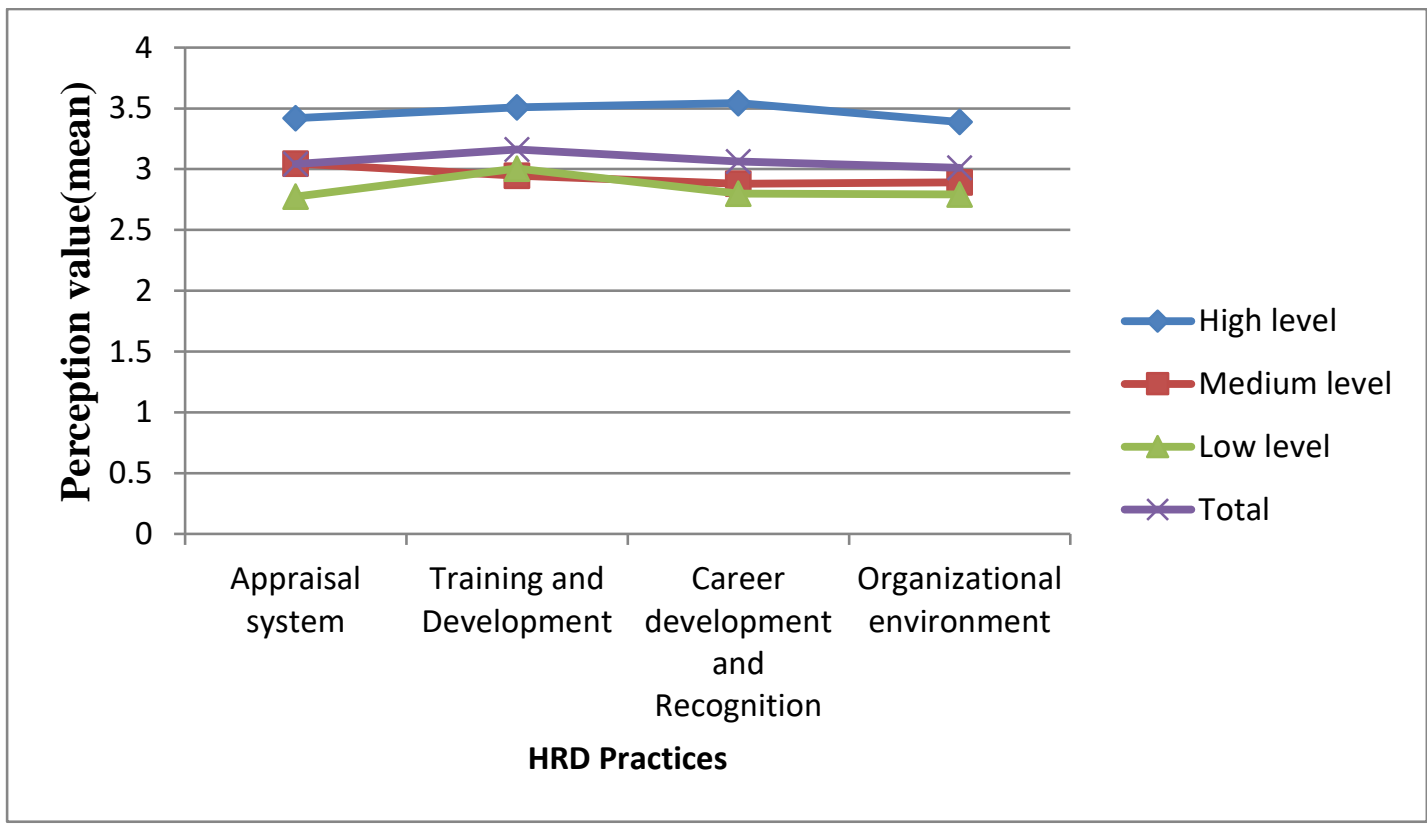

Source: Field survey (SPSS Output)

Figure 3: HRD practices of small size NPOs 
From the ANOVA test results (Table 32) it is evident that HRD practices play a prominent role in utilizing the foreign contributions received by NPOs. The $p$ value is $<0.05$ in all the cases. Therefore, the null hypothesis is rejected and the research hypothesis "There is significant difference in the HRD practices of small size NPOs belonging to different utilization levels" stands accepted. It can be observed from the table that when the HRD score is less the level of utilization is low and when the HRD score is high the utilization level is high. This implies for the better utilization of foreign contributions HRD practices are essential. Small size NPOs should adapt better HRD practices to utilize the contributions to the full extent. Overall, from the hypothesis testing it is clear that better HRD practices leads higher utilization of contributions and increases the efficiency of small size NPOs.

\section{F. Impact of HRD practices on efficiency of NPOs in utilizing contributions.}

To measure the impact of HRD practices on efficiency of NPOs in utilizing Foreign Contributions regression analysis were performed.

\section{Regression analysis}

For regression analysis, this study used the percentage scores of NPOs in utilizing FC received as dependent variable. The average of HRD scores is considered as independent variable. Accordingly, four simple regression models were developed in this study. One for large size NPOs, second for medium size NPOs, third for small size NPOs and fourth for all NPOs.

To measure the impact of HRD Practices on Efficiency of NPOs following hypothesis was formulated. $\mathrm{H}_{0}$ : There is no significant impact of HRD practices on the efficiency of NPOs. $\mathrm{H}_{1}$ : There is significant impact of HRD practices on the efficiency of NPOs

\section{Table 10: Results of simple Regression Analysis}

\begin{tabular}{|c|c|c|c|}
\hline Type of NPOs & Beta & t-value & p-value \\
\hline Large size NPOs & .421 & 2.453 & $.021^{*}$ \\
\hline Medium size NPOs & .411 & 2.388 & $.024^{*}$ \\
\hline Small size NPOs & .324 & 1.811 & $.081^{* *}$ \\
\hline All NPOs & .154 & 4.309 & $.000^{*}$ \\
\hline
\end{tabular}

*p-value is significant at 0.05 level, $* *$ p-value is insignificant at 0.05 level

The results of the simple regression analysis are present in table 10. The simple regression results reject the null hypothesis and accepts the research hypothesis as the p-value is $<0.05$ in large and medium size NPOs. in case of small size NPOs the p-value is $>0.05$ hence the null hypothesis is accepted and research hypothesis is rejected. The results show that there is a significant impact of HRD practices on the efficiency of NPOs in utilizing the foreign contributions. It is evident that HRD practices of large size and medium size NPOs have significant impact of efficiency, whereas the HRD practices of small size do not have a significant impact on efficiency of NPO in utilizing the foreign contributions.

\section{Major Findings}

The NPO's workforce has positively perceived HRD practices followed in their organization. The respondents have agreed and given a positive opinion towards the HRD practices viz., appraisal system, Training and development, career development and recognition, and organizational environment followed in their organizations. The mean values of all the variables were compared with hypothesized t-values and significant results are obtained to support the research hypothesis. Over five years, the average amount of Foreign Contributions received by NPOs is increasing. Large-sized NPOs are generating a larger amount, whereas smallsized NPOs are receiving fewer foreign contributions.

NPOs with better HRD practices are efficient in utilizing the foreign contributions received by them. The efficiency of the NPOs increases as they adapt better HRD practices, and the efficiency of NPOs decrease as they 
ignore HRD practices. The efficiency of large-size NPOs is high with better HRD practices and low when HRD practices are not emphasized. The medium-sized NPOs that follow HRD practices are efficient. The small size NPOs with enhanced HRD practices is reporting high-level efficiency in utilizing foreign contributions. From the regression analysis it is found that the HRD practices have a significant impact on increasing the efficiency of NPOs in utilizing foreign contributions.

\section{Suggestions}

It is suggested that large size NPOs should improve training system to increase their efficiency in utilizing foreign contributions received. A good training system also ensures that employees and volunteers develop in areas corresponding to their career plans. Training cannot be a one-time event; it is essential to define and support continuous learning paths. Trainees should be given ample time and support to try out new things with the required tools and technologies. Overall medium size NPOs lack maintaining the favorable organizational environment. Hence it is suggested to improve the workplace environment to increase efficiency. Overall, small-sized NPOs have a better training system, but they lack a favorable organizational environment. Hence, it is suggested that small size NPOs should continue their existing training system to increase their efficiency in utilizing foreign contributions received. But they should improve in maintaining the organizational environment. NPOs should encourage volunteers and other employees to work with enthusiasm. Recognizing the efforts of employees and volunteers will increase their job satisfaction. Organizations with high levels of employee job satisfaction are able to recruit better talent in the long run.

\section{Conclusion}

HRD practices have a substantial influence on the operation of NPOs. There exists an extensive body of knowledge and recommendations which were originally developed for profit-oriented organizations that can be applied to NPOs as well. But while adopting such methods special characteristics of NPOs must be considered. It is necessary that the implementation process taps into the competence and creativity of employees and helps in increasing the efficiency of NPOs. It is known from the literature that NPOs are practicing different HR strategies, but they lack professionalism when compared to profit-oriented organizations. Through proper implementation of best HRD practices NPOs can increase their efficiency in utilizing the foreign contributions received.

\section{References}

[1] Akingbola, K. (2006). Strategy and HRM in nonprofit organizations: evidence from Canada The International Journal of Human Resource Management, 37-41. https://doi.org/10.1080/09585190600964350

[2] Alfes, K., Antunes, B., \& Shantz, A. D. (2016). The management of volunteers - what can human resources do? A review and research agenda. The International Journal of Human Resource Management, 1-36. https://doi.org/10.1080/09585192.2016.1242508

[3] Anheier, H. K. (2000). Managing non-profit organisations: Towards a new approach. Civil Society Working Paper 1, (January), 21. https://doi.org/0753013436

[4] Ben-Ner, A., \& Ren, T. (2015). Comparing workplace organization design based on form of ownership: Nonprofit, for-profit, and local government. Nonprofit and Voluntary Sector Quarterly, 44(2), 340-359.

[5] Brown, W. A., \& Yoshioka, C. F. (2003). Mission attachment and satisfaction as factors in employee retention. Nonprofit management and leadership, 14(1), 5-18

[6] Chang, W. W., Huang, C. M., \& Kuo, Y. C. (2015). Design of employee training in Taiwanese nonprofits. Nonprofit and Voluntary Sector Quarterly, 44(1), 25-46. https://doi.org/10.1177/0899764013502878

[7] Cunningham, I. (1999). Human resource management in the voluntary sector: Challenges and opportunities. Public Money and Management, 19(2), 19-25.

[8] Delaney, J. T., \& Huselid, M. A. (1996). The impact of human resource management practices on perceptions of organizational performance. Academy of Management journal, 39(4), 949-969. 
[9] Danileviciute,G.(2015).Work engagement in nonprofit organizations,Doctoral dissertation, Aarhus University School Of Business And Social Sciences Department Of Business Administration

[10] Davies, T. R. (2016). Understanding non-governmental organizations in world politics: The promise and pitfalls of the early 'science of internationalism. European Journal of International Relations, 233-240. https://doi.org/10.1177/1354066116679243

[11] Dolai, D. (2015). Perception of Employees on HRD Climate in Insurance Sector: Publicvs . Private, Paripix-Indian Journal of research (July), 328-330.

[12] Dolnicar, S., \& Lazarevski, K. (2009). Marketing in non-profit organization: an international perspective. International Marketing Review, 26(3), 275-291. https://doi.org/10.1108/02651330910960780

[13] Fowler, D. S. (2020). A Case Study of Organizational Performance and Improvement Suggestions Within the Nonprofit Religious Services Sector: A Human Resource Development Approach. Performance Improvement, 59(8), 6-11.

[14] Galle, B., \& Walker, D. I. (2016). Donor Reaction to Salient Disclosures of Nonprofit Executive Pay: A Regression-Discontinuity Approach. Nonprofit and Voluntary Sector Quarterly, 45(4), 787-805. https://doi.org/10.1177/0899764015609728

[15] Gamm, L., \& Kassab, K. (1983). Productivity Assessment of Volunteer Programs in Not-for-Profit Human Services Organizations. Journal of Voluntary Action Research, 12(3), 23-38.

[16] Gardner, J. R. (1987). The Ethics and Responsibilities of the Not-for-profit Manager. Nonprofit and Voluntary Sector Quarterly, 16(4), 6-14. https://doi.org/10.1177/089976408701600403

[17] Goulet, L. R., \& Frank, M. L. (2002). Organizational Commitment across Three Sectors: Public, Nonprofit, and For-profit. Public Personnel Management, 31(2), 201-210.

[18] Haley-Lock, a., Berman, D., \& Timberlake, J. M. (2013). Employment Opportunity for Workers Without a College Degree Across the Public, Nonprofit, and For-Profit Sectors. Work and Occupations, 40, 281311. https://doi.org/10.1177/0730888412475070

[19] Harris, E. E., \& Ruth, J. A. (2015). Analysis of the Value of Celebrity Affiliation to Nonprofit Contributions. Nonprofit and Voluntary Sector Quarterly, 44(5), 945-967. https://doi.org/10.1177/0899764014546428

[20] Harrison, Y. D., \& Murray, V. (2015). The Effect of an Online Self-Assessment Tool on Nonprofit Board Performance. Nonprofit and Voluntary Sector Quarterly, 44(6), 1129-1151. https://doi.org/10.1177/0899764014557361

[21] Johnson, M. F. (2003). Differential Taxation of for-Profit and Nonprofit Firms: A Computational General Equilibrium Approach. Public Finance Review, 31(6), 623-647. https://doi.org/10.1177/1091142103254579

[22] Kakumani Lavanya Latha, \& Kotte Prabhakar. (2011). Non-government organizaations: problems and remedies in India. Serbian Journal of Management, 6(1), 109-121. https://doi.org/10.5937/sjm1101109L

[23] Khan, N. A., \& Tarab, S. (2012). An Empirical Presentation of HRD Climate and Employee Development in Telecommunication Industry A Case Study of Indian Private Sector, 1(1), 1-10.

[24] Kim, M. (2016). Characteristics of Civically Engaged Nonprofit Arts Organizations: The Results of a National Survey. Nonprofit and Voluntary Sector Quarterly. https://doi.org/10.1177/0899764016646473

[25] Kim, M. Y., \& Park, S. M. (2017). Antecedents and outcomes of acceptance of performance appraisal system in Korean non-profit organizations. Public Management Review, 19(4), 479500.https://doi.org/10.1080/14719037.2016.1195436

[26] Liao-Troth, M. A. (2001). Attitude differences between paid workers and volunteers. Nonprofit Management and Leadership, 11(4), 423-442.

[27] Liket, K. C., \& Maas, K. (2015). Nonprofit Organizational Effectiveness: Analysis of Best Practices. Nonprofit and Voluntary Sector Quarterly, 44(2), 268-296. https://doi.org/10.1177/0899764013510064

[28] Lin, J. (2016). What Is Education For? A Discussion of Nussbaums Not for Profit: Why Democracy Needs the Humanities. Education and Urban Society, 48(8), 767-779. https://doi.org/10.1177/0013124516630603

[29] McGinnis Johnson, J., \& Ng, E. S. (2015). Money Talks or Millennials Walk: The Effect of Compensation on Nonprofit Millennial Workers Sector-Switching Intentions. Review of Public Personnel Administration, 1-23. https://doi.org/10.1177/0734371X15587980 
[30] Nevarez, L. (2000). Corporate philanthropy in the new urban economy - The role of business-nonprofit realignment in regime politics. Urban Affairs Review, 36(2), 197-227. https://doi.org/10.1177/10780870022184831

[31] Noonan, D. S., Matisoff, D. C., \& Hoelzel, N. Z. (2016). Characteristics of Voluntary Behavior in the Neighborhood Commons: The Case of Dog Parks. Nonprofit and Voluntary Sector Quarterly, 45(4S), 78S-96S. https://doi.org/10.1177/0899764016651728

[32] Patel, B. S., Booker, L. D., Ramos, H. M., \& Bart, C. (2015). Mission statements and performance in non-profit organisations. Corporate Governance.. https://doi.org/10.1108/CG-07-2015-0098

[33] Penn, H. (2011). Gambling on the market: The role of for-profit provision in early childhood education and care. Journal of Early Childhood Research ,9(2), 150-161. https://doi.org/10.1177/1476718X10387999

[34] Rao, T. V. (2015). Human Resource Development as National Policy in India, 6(3), 288-296. https://doi.org/10.1177/1523422304266075

[35] Rao, T. V., \& Abraham, E. (1986). Human resource development: Practices in Indian industries: A trend report. Management \& Labour Studies.73-85

[36] Rao, T.V. \& Pereira, D.F. (1986), Recent Experiences in HRD, Oxford and IBH Publishing Co. Pvt. Ltd., New Delhi

[37] Ravichandran, N. (2006). Regulatory Challenges and Non-profit Welfarism: Implications and a Sustainable Framework for Choice. Journal of Health Management, 8(2), 261-294. https://doi.org/10.1177/097206340600800207

[38] Saraswathi, S. (2010). Human resources development climate: An empirical study. International Journal of Innovation, Management and Technology, 1(2), 174.

[39] Sutton, S. a. (2010). Rethinking Commercial Revitalization: A Neighborhood Small Business Perspective. Economic Development Quarterly, 24(4), 352-371. https://doi.org/10.1177/0891242410370679

[40] Tandon, R. (2017). The Hidden Universe of Non-profit Organisations in India. Economic and Political Weekly, 52(3).

[41] Tang, F. (2015). Retirement patterns and their relationship to volunteering. Nonprofit and Voluntary Sector Quarterly, 1-21. https://doi.org/10.1177/0899764015602128

[42] Taylor, T., \& McGraw, P. (2006). Exploring human resource management practices in nonprofit sport organisations. Sport Management Review, 9(3), 229-251. 